\title{
Pelatihan Pengolahan Makanan dengan Bahan Hasil Pertanian Masyarakat
}

Ani Wijayanti ${ }^{1}$, Emmita Devi Hari Putri ${ }^{2}$, Citra Unik Mayasari ${ }^{3}$, M.Fathurrahman Nurul Hakim ${ }^{4}$, Miftah Arif Fiyan ${ }^{5}$, dan Dhimas Setyo Nugroho ${ }^{6}$

${ }^{1}$ Universitas Bina Sarana Informatika, Yogyakarta, Indonesia, Email: citra.cyu@bsi.ac.id

${ }^{2}$ Universitas Terbuka, Yogyakarta, Indonesia, Email: dhimas.nugroho@ecampus.ut.ac.id

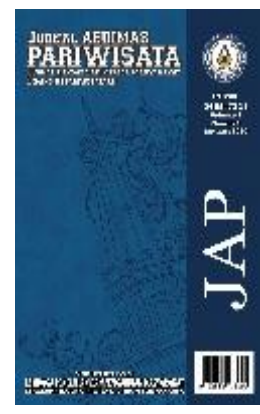

\begin{tabular}{|c|c|}
\hline \multicolumn{2}{|c|}{ Informasi artikel } \\
\hline $\begin{array}{l}\text { Sejarah } \\
\text { artikel }\end{array}$ & \\
\hline Diterima & : 18 April 2019 \\
\hline Revisi & : 1 Mei 2019 \\
\hline Dipublikasikan & : 15 Januari 2020 \\
\hline
\end{tabular}

\section{Kata kunci:}

Puncak Sosok (Jabal Kelor)

Keripik daun kelor

BSI

\begin{abstract}
ABSTRAK
Destinasi wisata Puncak Sosok yang berada di Desa Bawuran ini memiliki sumber daya alam berupa tanaman kelor yang sangat berlimpah. Hingga saat ini masyarakat belum bisa memanfaatkan kelor menjadi olahan yang bervariasi dan memiliki nilai jual. Program pengabdian kepada masyarakat ini bertujuan untuk meningkatkan pengetahuan dan ketrampilan tentang pemanfaatan daun kelor, melatih dan menumbuhkan jiwa wirausaha kepada masyarakat sehingga dapat meningkatkan perekonomian masyarakat desa Bawuran. Sasaran pada kegiatan pengabdian masyarakat ini adalah masyarakat desa Bawuran, pengelola wisata Puncak Sosok dan pedagang Puncak Sosok. Metode yang digunakan dalam pengabdian ini dilakukan dalam beberapa tahap meliputi ; identifikasi, sosialisasi, pelatiham dan pendampingan. Pengabdian kepada masyarakat ini memberikan beberapa manfaat terhadap masyarakat yaitu terjadi peningkatan pengetahuan masyarakat tentang manfaat kelor dan pemanfaatannya serta menanamkan jiwa wirausaha. Bagi pedagang dapat menambah pengetahuan tetang pengolahan variasi produk makanan yang dapat dijual di Puncak Sosok. Bagi pengelola wisata pelatihan ini dapat menciptakan product image (makanan khas) bagi destinasi wisata Puncak Sosok.
\end{abstract}

Keywords:

Puncak Sosok (Jabal Kelor) moringa leaf chips

$B S I$

\begin{abstract}
Food Processing Training with Community Agricultural Products

The Sosok Peak tourist destination in the village of Bawuran has abundant natural resources in the form of Moringa plants. Until now, the community has not been able to use Moringa plant to be used as a variety of processed products and has a resale value. This community service program aims to increase the knowledge and skills regarding the use of Moringa leaves. To train and grow an entrepreneurial spirit to the community so that it can improve the economy of the Bawuran village community. The targets of community service activity are the people of Bawuran village, Sosok Peak's tourism manager and the merchants. The method used in this community service is carried out in several stages including identification, socialization, training and assistance. Community service has provided several benefits to the community, namely an increase in community knowledge about the benefits of Moringa and its use as well as introducing an entrepreneurial spirit. For traders, they can increase their knowledge about processing various food products that can be sold at Sosok Peak. For the tourism manager, this training can create a product image (typical food) for the Sosok Peak tourist destination
\end{abstract}




\section{Pendahuluan}

Destinasi wisata Puncak Sosok (Jabal Kelor) yang berlokasi di Desa Bawuran Pleret Bantul Yogyakarta, merupakan salah satu destinasi wisata yang sedang berkembang. Wisata Puncak Sosok ini diresmikan pada bulan Desember 2017. Menurut I Pitana dalam (Hermawan, 2016) Pembangunan dan pengembangan pariwisata secara langsung mampu menyentuh dan melibatkan masyarakat sehingga membawa berbagai dampak terhadap masyarakat setempat, baik dampak positif maupun negatif. Pengembangan wisata di Puncak Sosok (Jabal Kelor) melibatkan masyarakat setempat secara langsung, salah satunya berupa pengelolaan warung makan yang di kelola oleh masyarakat setempat. Keterlibatan tersebut memberikan dampak positif bagi masyarakat yakni peningkatan perekonomian. Pengelola wisata Puncak Sosok melakukan pengembangan daya tarik wisata, fasilitas wisata, sarana dan prasarana wisata secara terus-menerus. Pengembangan yang menjadi prioritas saat ini yakni, pemanfaatan sumber daya alam lokal menjadi produk unggulan dan mampu menarik minat kunjungan wisatawan. Selain menjadi produk unggulan di harapkan mampu meningkatkan perekonomian masyarakat setempat.

Destinasi wisata Puncak Sosok (Jabal Kelor) mempunyai sumber daya alam berupa tanaman kelor yang sangat berlimpah. Tanaman kelor sudah di kenal sampai dengan mancanegara, sebagai tanaman yang mampu mengatasi masalah gizi. Tanaman kelor (Moringa Olieferia) mempunyai berbagai manfaat, diantaranya sumber nutrisi, pengobatan alami, dan bahan kosmetik (Aminah et al., 2015). Tanaman kelor dapat di olah menjadi berbagai jenis produk olahan, yaitu produk fortifikasi atau aneka makanan dan minuman, produk farmasi, dan olahan tepung (Aminah et al., 2015). Tanaman kelor mempunyai sifat fungsional dalam menanggulangi kekurangan nutrisi dan menjaga kesehatan. Tanaman kelor mengandung nutrisi mikro sebanyak empat kalsium susu, empat kali potassium pada buah pisang, protein pada dua botol yogurt, tujuh kali vitamin $\mathrm{C}$ pada buah jeruk, dan empat kali vitamin A pada wortel. Selain dampak positif tanaman ini juga memiliki dampak negatif, yakni dapat menyebabkan kembung karena mengandung finosa, sukrosa, dan stakiosa (Gupta et.al., 1989). Namun demikian, dampak negatif tersebut dapat di tanggulangi dengan melakukan proses fermentasi (Roopashri dan Varadaraj, 2014).

Tanaman kelor yang mengandung nutrisi tinggi tersebut harus di olah secara tepat, supaya nutrisi yang terkandung di dalamnya tidak rusak. Dalam pengolahan tanaman kelor harus memperhatikan suhu, proses, pemanasan, penyimpanan, dan perlakuan terhadap tanaman itu sendiri. Semua bagian dari tanaman kelor dari daun, kulit batang, biji hingga akar merupakan sumber nutrisi dan berfungsi sebagai herbal (Simbolan et al., 2007). Akar kelor dapat digunakan sebagai obat balur, dengan cara dihaluskan dengan tanaman lain. Jika di rebus akar kelor dapat djadikan sebagai obat rematik dan epilepsi. Daun kelor di tambah dengan kapur sirih bisa menjadi obat untuk penyakit kulit, adapun biji kelor dapat di manfaatkan sebagai penjernih air. Sedangkan pohon kelor berfungsi sebagai tanaman yang dapat menahan longsor dan terasering (Nurcahyati, 2014).

Tanaman kelor yang terdapat di Puncak Sosok (Jabal Kelor) belum di olah dan di manfaatkan secara maksimal. Pengolahan tanaman kelor masih sangat terbatas baru sebagai olahan pelengkap sayuran dari sego wiwit, yakni salah satu produk kuliner yang diperuntukkan atau di jual bagi para pengunjung wisata Puncak Sosok. Tanaman kelor sendiri dapat diolah menjadi berbagai produk olahan, diataranya: cake, biscuit, teh herbal, tepung nuget, pudding, keripik, permen, dan yogurt. Tanaman kelor yang di olah secara maskimal mampu meningkatkan nilai ekonomi dari tanaman itu sendiri, sehingga mampu meningkatkan kesejahteraan mesyarakat setempat. Upaya pengolahan tanaman kelor di Pucak Sosok dapat dilakukan dengan melibatkan berbagai stake holder, salah satunya dari para akademisi yang memiliki pengetahuan dan ketrampilan dalam pengolahan tanaman kelor.

\section{Metode}

Metode yang digunakan dalam pengabdian masyarakat tentang pemanfaatan bahan baku lokal berupa tanaman kelor yang sangat berlimpah di desa Bawuran ini, dilakukan dalam beberapa tahapan meliputi; identifikasi, sosialisasi, pelatihan dan pendampingan. 
Identifikasi

Kegiatan yang dilakukan berupa pemetaan permasalahan yang di hadapi masyarakat di Wisata Puncak Sosok, terutama yang berkaitan dengan pemanfaatan sumber daya alam lokal. Identifikasi dilakukan melalui proses observasi dan wawancara. Observasi atau pengamatan di lapangan dilakukan untuk memperoleh gambaran secara detail mengenai kondisi di destinasi Wisata Puncak Sosok. Sedangkan informasi lebih lengkap diperoleh melalui wawancara dengan beberapa informan kunci, yakni pengelola dan masyarakat setempat yang terlibat langsung dalam pengelolaan destinasi wisata Puncak Sosok. Dari hasil pemetaan permasalahan terkait pemanfaatan sumber daya alam lokal, teridentifikasi sumber daya alam lokal berlimpah yang belum di olah atau dimanfaatkan secara optimal yakni tanaman kelor.

\section{Sosialisasi}

Kegiatan yang dilakukan berupa penyuluhan melalui paparan materi pemanfaatan sumber daya lokal guna meningkatkan kesejahteraan masyarakat. Kegiatan sosialisasi bertujuan membuka wawasan dan meningkatkan kesejahteraan masyarakat dalam pemanfaatan bahan baku lokal sebagai salah satu upaya meningkatkan pendapatan ekonomi.

\section{Pelatihan}

Berdasarkan hasil pemetaan masalah, langkah selanjutnya dilakukan pelatihan sesuai dengan kebutuhan di destinasi wisata Puncak Sosok, yakni pelatihan pengolahan daun kelor. Pelatihan yang di pilih kali ini adalah mengolah daun kelor menjadi keripik yang dapat menjadi alternatif makanan ringan yang sehat. Pelatihan dilakukan selama satu hari, pada hari Sabtu, 26 Januari 2019. Adapun peserta pelatihan terdiri dari kelompok sadar wisata atau pengelola wisata puncak sosok, ibu-ibu PKK, dan para pedagang makanan di destinasi wisata Puncak Sosok.

\section{Pendampingan}

Program pendampingan merupakan kegiatan lanjutan yang dilakukan secara berkala pasca pelatihan. Pendampingan dimaksudkan untuk memberikan dukungan secara terus menerus, baik dari aspek pengetahuan maupun keterampilan bagi masyarakat setempat. Melalui pendampingan diharapkan pelatihan dapat di implementasikan secara maskimal dan memberikan dampak positif bagi masyarakat setempat pada khususnya dan masyarakat luas pada umumnya.

Sedangkan untuk susunan panitia pelaksana kegiatan pengabdian :

Penanggunjawab

: Ani Wijayanti, S.E.,M.M

Ketua Pelaksana

: Emmita Devi Hari Putri, S.Par.,M.M

Koordinator Tutor

: Citra Unik Mayasari,S.ST.Par.,M.M

Anggota

: M.Fathurrahman Nurul Hakim, S.ST.Par,M.M

: Miftah Arif Fiyan,S.ST.Par,M.M

: Dhimas Setyo Nugroho,S.Par,M.M

Mahasiswa

: Dinda Puspa Prastiyanti

: Anggi Nurlita Wulandari

: Novita Dwi Agilika

\section{Hasil dan Pembahasan}

\section{Profil Destinasi Wisata Puncak Sosok (Jabal Kelor)}

Puncak Sosok atau Jabal Kelor merupakan salah satu destinasi wisata baru yang terletak di Dadap Kulon, Desa Bawuran, Kecamatan Pleret, Kabupaten Bantul, Provinsi Daerah Istimewa Yogyakarta. Puncak Sosok merupakan destinasi kedua setelah Puncak Gebang, yang kurang lebih berjarak $1 \mathrm{~km}$. Puncak Sosok di ciptakan oleh pemuda setempat untuk menghidupkan wisata di daerah Bawuran. Daya tarik yang ditawarkan berupa pemandangan senja yang indah, pemandangan alam yang asri dari atas bukit dan suasana perbukitan. Puncak Sosok kini mulai dikenal sejak tahun 2017. Perkembangan destinasi di awali dari kebiasaan pemuda pemudi berkumpul untuk merayakan acara pergantian tahun baru. Seiring dengan berjalannya waktu, semakin banyak masyarakat yang mengunjungi untuk melihat kembang api yang dinyalakan setiap malam pergantian tahun dari beberapa penjuru kota Yogyakarta. 
Upaya masyarakat dalam pengembangan destinasi wisata Puncak Sosok terlihat dari kerja keras yang dilakukan untuk membuka jalan menuju puncak sosok melalui gotong royong secara rutin. Pembukaan jalan menuju puncak sosok dilakukan melalui pemangkasan pepohonan untuk membuat jalur kendaraan bermotor. Sedangkan upaya yang dilakukan untuk menghidupkan destinasi wisata, yakni dengan mengadakan berbagai event untuk menarik minat pengunjung. Salah satu event besar yang di gelar di Puncak Sosok yaitu Kapolda Cup Bike Fest 2017. Destinasi wisata Puncak Sosok dapat dilihat pada Gambar 1.

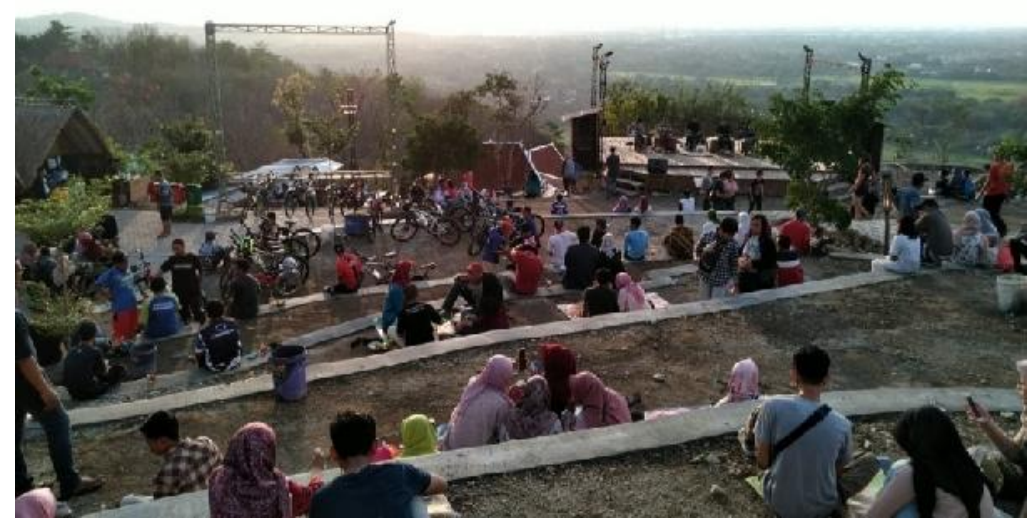

Gambar 1. Puncak Sosok

\section{Pengolahan Keripik Berbahan Dasar Daun Kelor}

Pengolahan keripik berbahan dasar kelor merupakan salah satu upaya pemanfaatan sumberdaya lokal yang berlimpah di puncak sosok. Pemanfaatan sumber daya lokal merupakan salah satu langkah strategi supaya pemberdayaan sumber daya dan meningkatkan nilai ekonomis. Pemanfaatan sumber daya lokal mampu memberikan kontribusi pada proses pembangunan yang berkelanjutan, serta membantu meningkatkan kesejahteraan masyarakat. Proses pengolahan keripik berbahan dasar daun kelor dilakukan melalui beberapa tahapan, yakni penyiapan bahan dan penyiapan alat, proses pengolahan, pengemasan, dan perhitungan harga pokok produksi.

\section{Penyiapan bahan}

Bahan utama yang diperlukan dalam pembuatan keripik ini yakni daun kelor. Daun kelor mempunyai bentuk bulat telur dengan ukuran yang kecil, majemuk, memiliki tangkai panjang dan tersusun secara selang-seling. Helai daun kelor yang masih muda akan berwarna hijau segar. Daun kelor sebagai bahan dasar pembuatan Keripik dapat dilihat pada Gambar 2. 


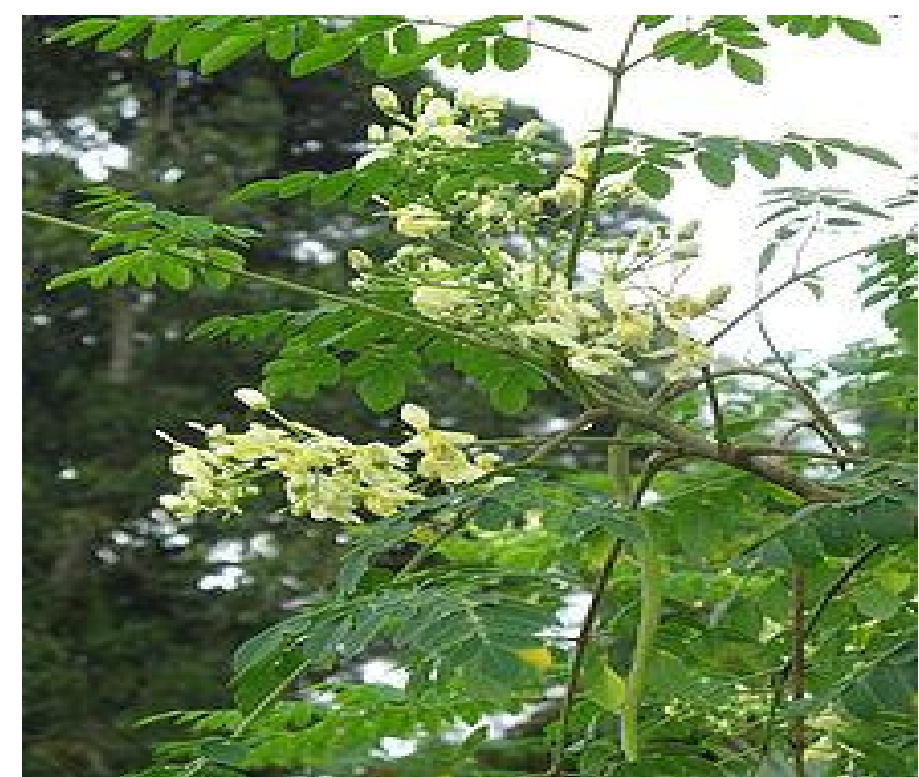

Gambar 2. DaunKelor (https://id.wikipedia.org/wiki/Kelor, 12 Desember 2019)

Daun kelor yang jarang dikonsumsi akan memiliki rasa pahit, maka daun kelor harus sering dipanen untuk menghilangkan rasa pahit (Hariana, 2008). Daun kelor yang sudah di petik harus segera di olah karena jika terlalu lama di biarkan dia akan berubah warna menjadi agak kuning dan layu. Setelah mendapatkan daun kelor yang berkualitas sebagai bahan pembuatan keripik, langkah selanjutnya menyiapkan bahan-bahan pelengkap lainnya. Bahan pembuatan keripik disajikan pada Tabel 1.

Tabel 1. Bahan Keripik Daun Kelor

\begin{tabular}{|l|l|c|}
\hline No & \multicolumn{1}{|c|}{ Bahan } & Jumlah \\
\hline 1 & Daun Kelor & $3 \mathrm{~kg}$ \\
\hline 2 & Bawang putih & $700 \mathrm{gr}$ \\
\hline 3 & Ketumbar & $100 \mathrm{gr}$ \\
\hline 4 & Tepung tapioca & $1,5 \mathrm{~kg}$ \\
\hline 5 & Tepung beras & $3 \mathrm{~kg}$ \\
\hline 6 & Garam & 100 \\
\hline 7 & Kaldu bubuk & $4 \mathrm{bks}$ \\
\hline 8 & Lada Halus & $2 \mathrm{bks}$ \\
\hline 9 & Minyak Goreng & $1 \mathrm{ltr}$ \\
\hline
\end{tabular}

Sumber :Penulis, 2019

Penyiapan Alat

Berbaga peralatan utama yang diperlukan dalam pembuatan keripik daun kelor disajikan pada Tabel 2.

Tabel 2. Alat ntuk Pembuatan Keripik Daun Kelor

\begin{tabular}{|c|l|l|}
\hline No & Item & Jumlah \\
\hline 1 & Tabung Gas + Gas $12 \mathrm{~kg}$ & 1 unit \\
\hline 2 & Panci & 2 unit \\
\hline 3 & Wajan & 2 unit \\
\hline 4 & Kompor & 1 unit \\
\hline 5 & Plastik Kemasan & 10 unit \\
\hline 6 & Pisau & 2 unit \\
\hline 7 & Lidel & 2 unit \\
\hline 8 & Tambir & 2 unit \\
\hline 9 & Ember tangkai & 1 unit \\
\hline 10 & Talenan & 1 unit \\
\hline
\end{tabular}

Sumber :Penulis, 2019 
Proses pengolahan

Adapun setelah bahan dan peralatan tersedia selanjutnya adalah memasuki tahap pengolahan keripik berbahan dasar daun kelor, berikut ini merupakan diagram alir dalam proses pengolahan keripik daun kelor yang dapat di lihat pada Gambar 3.

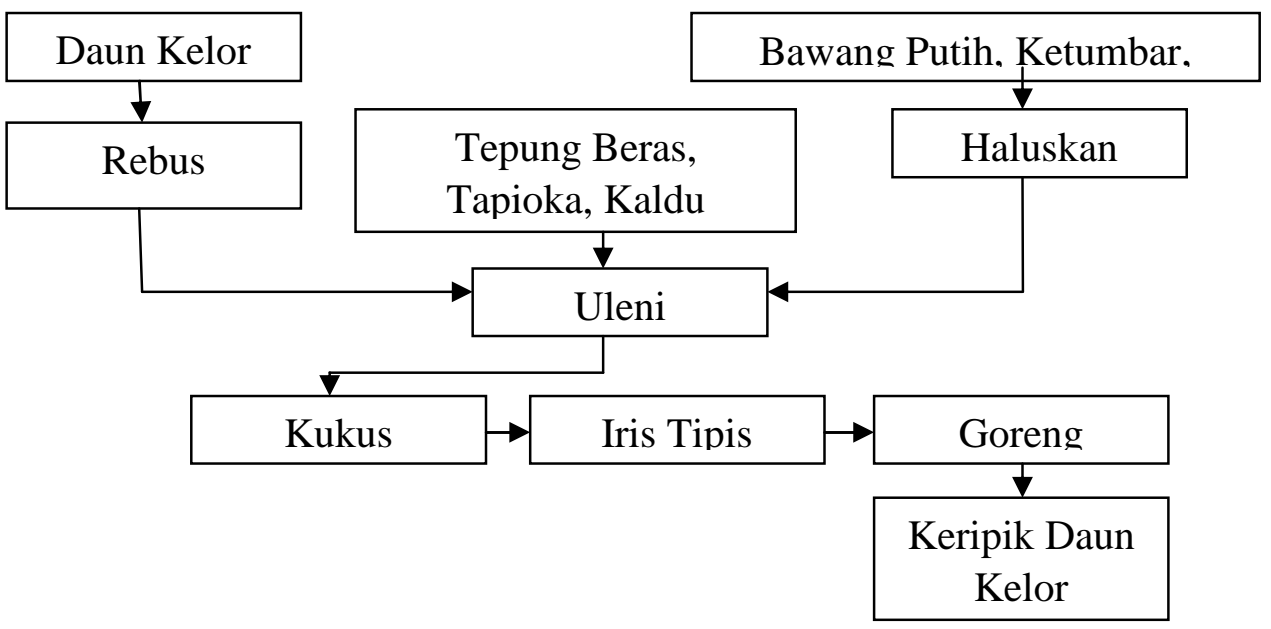

Gambar 3. Diagram Alir Proses Pengolahan Keripik Daun Kelor

Sumber : Penulis (2019)

Proses Pengolahan Keripik Daun Kelor :

1. Siapkan daun kelor petik daun dari batangnya. Cuci atau bersihkan daun kelor kemudian rebus air hingga mendidih. Setelah mendidih rebus daun kelor sebentar hingga matang. Angkat dan tiriskan.

2. Haluskan bumbu bawang putih, ketumbar dan garam, campur dengan daun kelor yang sudah di rebus.

3. Kemudian masukan telur, kaldu bubuk, tepung tapioka dan tepung beras sedikit demi sedikit. Uleni adonan hingga menjadi kalis (tidak lengket).

4. Setelah adonan menjadi kalis, masukkan ke dalam plastik atau gulung berbentuk bulat seperti lontong.

5. Kukus adonan yang sudah di gulung sekitar 60 menit.

6. Setelah matang adonan di dinginkan terus di potong tipis.

7. Siapkan minyak panas, goreng adonan keripik yang sudah di iris tipis dengan menggunakan minyak yang banyak dan api kecil. Angkat kemudian tiriskan.

8. Keripik siap di sajikan atau di kemas.

\section{Pengemasan}

Salah satu hal yang menarik dari sebuah produk adalah pegemasannya. Selain sebagai daya tarik fungsi utama kemasan adalah untuk menjaga kualitas produk dan menambah estetika dan nilai jualnya. Dalam pengemasan keripik daun kelor ini menggunakan kemasan plastik yang trasnparan agar keripik daun kelor dapat terlihat dengan harapan dapat menarik perhatian pembeli. Berikut ini adalah salah satu contoh hasil keripik yang sudah di kemas menggunakan plastik kemasan : 


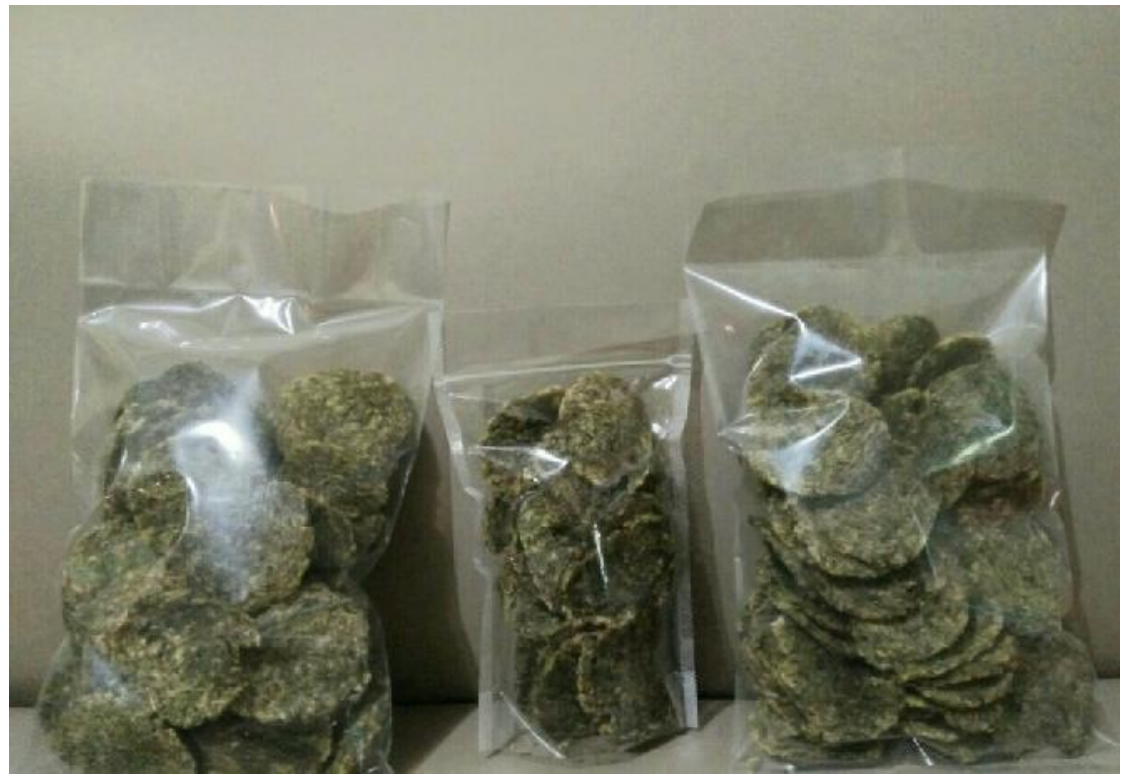

Gambar 4. Keripik Daun Kelor Sumber : Penulis (2019)

Selain pengemasan perlu juga di cantumkan label makanan yang dapat menguatkan branding sebuah produk tersebut. Label pada kemasan keripik daun kelor ini mencakup tentang nama produk, informasi berat bersih, informasi lengkap produsen, komposisi, legalitas dan tanggal kadaluwarsanya.

Perhitungan Harga Pokok Penjualan (HPP)

Selain memberikan pelatihan tentang pengolahan produk keripik daun kelor, kami dari tim PKM juga memberikan pelatihan tentang perhitungan Harga Pokok Penjualan (HPP). Tujuannya adalah untuk memberikan ilmu pengetahuan kepada masyarakat dalam menghitung biaya langsung yang dikeluarkan dalam pembuatan keripik daun kelor dan menentukan harga jualnya. Berikut ini adalah penghitungan HPP dalam pengolahan keripik daun kelor :

Tabel 3. Perhitungan Harga Pokok Penjulan Keripik Daun Kelor

\begin{tabular}{|c|c|c|c|c|c|c|}
\hline \multicolumn{2}{|c|}{$\begin{array}{l}\text { Nama } \\
\text { Jumlah Porsi }\end{array}$} & \multicolumn{2}{|c|}{$\begin{array}{l}\text { Keripik Daun Kelor } \\
: 10 \text { bks }\end{array}$} & $\begin{array}{l}\text { Cost per porsi } \\
\text { Harga Jual }\end{array}$ & $\begin{array}{l}: \operatorname{Rp} 9.552 \\
: \operatorname{Rp} 13.37\end{array}$ & \\
\hline \multirow{2}{*}{ No } & \multirow{2}{*}{ Bahan } & \multicolumn{2}{|c|}{ Kuantitas } & \multicolumn{2}{|c|}{ Harga Pasar } & \multirow{2}{*}{ Biaya } \\
\hline & & Jumlah & Satuan & Jumlah & Harga & \\
\hline 1 & Daun Kelor & 3000 & $\mathrm{gr}$ & $1000 \mathrm{gr}$ & Rp 3.000,00 & Rp $9.000,00$ \\
\hline 2 & Bawang putih & 700 & $\mathrm{gr}$ & $1000 \mathrm{gr}$ & Rp 18.000,00 & $\operatorname{Rp} 12.600,00$ \\
\hline 3 & Ketumbar & 100 & $\mathrm{gr}$ & $1000 \mathrm{gr}$ & $\operatorname{Rp} 24.000,00$ & Rp 2.400,00 \\
\hline 4 & Tepung tapioka & 1500 & $\mathrm{gr}$ & $1000 \mathrm{gr}$ & Rp 11.000,00 & Rp 16.500,00 \\
\hline 5 & Tepung beras & 3000 & $\mathrm{gr}$ & $1000 \mathrm{gr}$ & $\mathrm{Rp} 12.000,00$ & Rp 36.000,00 \\
\hline 6 & Garam & 100 & $\mathrm{gr}$ & $500 \mathrm{gr}$ & $\mathrm{Rp} 4.100,00$ & $\mathrm{Rp} 820,00$ \\
\hline 7 & Kaldu bubuk & 4 & bks & $12 \mathrm{bks}$ & Rp 5.000,00 & Rp $1.700,00$ \\
\hline 8 & Lada Halus & 2 & bks & $1 \mathrm{bks}$ & Rp 1.000,00 & Rp 2.000,00 \\
\hline 10 & Minyak goreng & 1 & Ltr & $1 \mathrm{ltr}$ & $\mathrm{Rp} 12.000,00$ & $\mathrm{Rp} 12.000,00$ \\
\hline 10 & $\begin{array}{l}\text { Plastik } \\
\text { Pembungkus }\end{array}$ & 10 & bks & $1 \mathrm{bks}$ & Rp 250,00 & Rp 2.500,00 \\
\hline \multicolumn{6}{|c|}{ Total Cost } & Rp $95.520,00$ \\
\hline
\end{tabular}

Sumber : Penulis (2019) 
Cost $/$ Portion $=$ Total Cost
Number of Portion

Selling Price $/$ Portion $=$ Cost $/$ Portion + Cost $\%=\operatorname{Rp~9.552,00~}+40 \%=\operatorname{Rp} 13.372,00$

Dalam satu resep keripik daun kelor bisa menjadi 10 bungkus keripik daun kelor yang siap untuk di jual. Total biaya yang di butuhkan dalam pembuatan satu resep keripik daun kelor adalah $\mathrm{Rp}$ 95.520,00. Biaya yang di butuhkan dalam 1 porsi (cost per portion) adalah Rp 9.552,00. Sehingga dengan mengambil untung $40 \%$ makan masyarakat bisa menjual keripik daun kelor dengan harga kurang lebih Rp 13.372,00 atau Rp 15.000,00 pada setiap bungkusnya.

Manfaat pelatihan bagi masyarakat

Kegiatan pengabdian masyarakat ini diharapkan dapat memberikan kebermanfaatan bagi masyarakat desa Bawuran dan peserta pelatihan antara lain :

1. Menambah ilmu pengetahuan dan ketrampilan tentang pemanfaatan daun kelor.

Peserta pelatihan dapat lebih memahami dan mengenal manfaat atau kandungan yang ada di daun kelor. Selain itu masyarakat juga mendapatkan bekal ketrampilan dalam memanfaatkan bahan baku lokal berupa daun kelor menjadi olahan makanan yang memiliki nilai jual.

2. Menumbuhkan jiwa wirausaha kepada masyarakat.

Setelah pelatihan ini selesai dilaksanakan diharapkan jiwa wirausaha dapat tumbuh di masyarakat dan peserta pelatihan, sehingga dapat meningkatkan kemandirian dan kesejahteraan secara mandiri.

3. Meningkatkan perekonomian masyarakat sekitar.

Pemanfaatan daun kelor sebagai olahan makanan yang bervariasi dapat meningkatkan estetika dan nilai jual produk tersebut, sehingga secara tidak langsung akan berpengaruh terhadap peningkatan perekonomian masyarakat.

4. Menciptakan product image untuk objek wisata tersebut.

Seorang wisatawan atau pelanggan biasanya akan membeli sesuatu makanan yang unik atau jarang ditemuinya. Keripik daun kelor merupakan suatu produk makanan yang masih jarang ditemui, sehingga keripik daun kelor dapat menjadi sebuah makanan khas di wisata Puncak Sosok dan dijadikan sebagai jajanan khas atau product image di wisata Puncak Sosok.

5. Menambah variasi produk makanan yang di jual oleh pedagang di objek wisata puncak sosok.

Dengan adanya olahan produk makanan dari keripik daun kelor ini dapat meningkatkan jenis variasi makanan yang dapat di jual di area Wisata Puncak Sosok, karena menu yang bervariasi akan jauh lebih menarik bagi para wisatawan untuk memilih dan membeli.

\section{Simpulan}

Dengan adanya kegiatan pengabdian kepada masyarakat di desa Bawuran ini memberikan dampak positif terhadap masyarakat, pengelola wisata dan pedagang di area wisata puncak sosok yaitu terjadinya peningkatan pengetahuan dan ketrampilan tentang pemanfaatan bahan baku lokal daun kelor menjadi keripik daun kelor, sehingga dapat meningkatkan perekonomian masyarakat. Hasil pengabdian kepada masyarakat ini menghasilkan respon yang positif ditunjukan dengan banyaknya peserta pelatihan yang datang dan antusiasme dari peserta sangat tinggi dalam mengikuti pengabdian ini.

\section{Ucapan Terima Kasih}

Ucapan terimakasih di sampaikan kepada Universitas Bina Sarana Informatika yang bersedia mendanai kegiatan. Masyarakat desa Bawuran, pengelola dan pedagang di wisata Puncak Sosok yang telah bersedia menyiapkan tempat dan meluangkan waktunya untuk berpartisipasi aktif dalam kegiatan ini. Teman-teman yang sudah bekerja keras dalam pengabdian ini sehingga kegiatan berjalan dengan 


\section{Referensi}

Sayekti, Erviana Duwi, Dra. Aminah Asngad, M. Si., \& Siti Chalimah, Dr, MPd. (2016) . Aktivitas Antioksidan Teh Kombinasi Daun Katuk dan Daun Kelor dengan Variasi Suhu Pengeringan. Skripsi. Universitas Muhammadiyah Surakarta.

Suryati, Aris Priyadi, \& Bing Waluyo. (2019). Perjanjian Paket Wisata antara Fakultas Hukum Universitas Wijayakusuma Purwokerto dengan Biro Perjalanan Wisata CV Putra Wisata. Cakrawala Hukum: Majalah Ilmiah, 21 (1), 1-7.

Hermawan, Hary. (2016). Dampak Pengembangan Desa Wisata Nlanggeran Terhadap Ekonomi Masyarakat Lokal. Jurnal Pariwisata, III(2), 105-117.

Nurcahyati, Erna. (2014). Khasiat Dahsyat Daun Kelor. Jakarta : Jendela Sehat.

Gupta, K., Barat, G.K., Wagle, D.D., \& Chawla, H.K.L. (1989). Nutrient Contents and Antinutritional Factors in Conventional and Non Conventional Leafy Vegetables. Food Chemistry, 31, 105116.

Roopashri, A.N., \& Varadaraj, M.C. (2014). Causing Oligosaccharides by a-D- galactoisidase of a Probiotic Lactobacillus Plantarum MTCC Elaboration of Probiotic Attributes in Soybased Fermented Product. European Food Research and Technology, 239, 99-115.

Simbolan, J.M., M. Simbolan, N. Katharina. (2007). Cegah Mal Nutrisi dengan Kelor. Yogyakarta: Kanisius.

Hariana, A. (2008). Tumbuhan Obat dan Khasiatnya Seri 2. Depok: Penebar Swadaya.

Wikipedia. (2019). Kelor. https://id.wikipedia.org/wiki/Kelor di unduh 12 Desember 2019. 